\title{
COMPARATIVE STUDY OF LOW DOSE MAGNESIUM SULPHATE \& PRITCHARD REGIME FOR ECLAMPSIA \& IMMINENT ECLAMPSIA
}

\author{
N. S. Kshirsagar, Manisha Laddad, Amit Bafana
}

1. Professor. Department of Obstetrics \& Gynecology, Krishna Institute of Medical Sciences, Karad.

2. Assistant Professor. Department of Obstetrics \& Gynecology, Krishna Institute of Medical Sciences, Karad.

3. Private Practitioner.

\section{CORRESPONDING AUTHOR}

Dr. N. S. Kshirsagar,

8/1 Koyana Vasahat, Jakhinwadi Road,

Karad (District Satara), Maharashtra-415110,

E-mail: nkshirsagar49@yahoo.com

Ph: 00919890942781,00919422848305

ABSTRACT: BACKGROUND: Eclampsia/ Pre-eclampsia are leading causes of maternal mortality. Various mgso $_{4}$ regimes are used to control convulsions. As the Indian women have less weight low dose mgso $_{4}$ was used. AIMS OBJECTS: To study comparative efficacy of low dose mgso4 in controlling convulsions in Eclampsia and in preventing convulsions in imminent Eclampsia METHODS A MATERIALS: Randomised Prospective study in which 60 cases were studied with low does mgso $_{4}$ and 60 cases with Pritchard regime. Serum mg++ levels were studied in every patient. RESULTS: Convulsions were controlled in $90 \%$ cases of low dose regime and in $91.60 \%$ cases of Pritchard regime in eclampsia. The success rate in seizure Prophylaxis was $100 \%$ in both regimes for imminent eclampsia. CONCLUSIONS: Low dose mgso $_{4}$ regime is equally effective in controlling / preventing convulsions if compared with Pritchard regime

KEY WORDS: low dose mgso $_{4}$ regime - Pritchard regime - eclampsia

MESH TERM: Eclampsia prevention \& control

INTRODUCTION: Hypertensive disorders of pregnancy are responsible for $10 \%$ to $15 \%$ maternal deaths. They also account for high perinatal morbidity and mortality

In India prevalence of eclampsia ranges from 1 in 30 to 1 in 500 pregnancies (1\&2)

Management of the eclamptic patient is based on 4 Principles

1) Control of convulsions

2) Control of hypertension

3) General management

4) Obstetrical management

Several drugs (Mgso4, phenytoin, diazepam, pethidine) are used to control the convulsions but the drug of choice is $\mathrm{MgSO}_{4}$.

Dr Pritchard (1955) popularized $\mathrm{Mgso}_{4}$ regime for eclampsia / preeclampsia Magpie trial (2002) confirmed that $\mathrm{MgsO}_{4}$ scores over Phenytoin, diazepam in controlling convulsions. Indian women weigh much less than their counterparts in western world. Hence the doses that were suggested by western authors may be toxic for our patients Dr. Suman Sardesai etal (2003) advocated a regime of low dose $\mathrm{MgSO}_{4}$ We adopted the same regime in this study. 
Our purpose was to study its efficacy, advantages, its correlation with serum $\mathrm{mgsO}_{4}$ levels and to compare it with Pritchard regime.

METHODS: The present prospective study was undertaken at Krishna Institute of medical sciences, Karad (Maharashtra) It was approved by the ethical committee of the institute.

Inclusion Criteria - 1) Patients with eclampsia

2) Patients of imminent eclampsia

(i.e. pre- eclampsia with any of the associated symptoms viz. headache , epigastric pain, vomiting, visual symptoms etc.)

Exclusion Criteria: 1) Patients with associated complications like cerebrovascular accidents renal failure.

2) Patients with any other anticonvulsant treatment before admission (e.g. diazepam, phenytoin )

Regimes used - Either low dose $\mathrm{Mgso}_{4}$ or Pritchard regime

Randomization of patients - Alternate patient was selected for low dose or Pritchard regime.

\section{DOSAGES:}

1) Low dose regime - As advocated by Dr. Suman Sardesai

Loading dose: $4 \mathrm{gm}$ of $50 \% \mathrm{MgSO}_{4}$ diluted in normal saline (i.e.20 cc of $20 \%$ solution ) was given IV over 4 to 5 minutes.

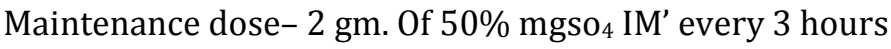

2) Pritchard regime -

Loading dose - IV $4 \mathrm{gm}$. Of $50 \% \mathrm{MgSO}_{4}$ diluted in normal saline (i.e. $20 \mathrm{cc}$ of $20 \%$ solution )

- $5 \mathrm{gm}$. Of $50 \% \mathrm{mgsO}_{4} \mathrm{IM}$ in each buttock

Thus total loading dose was $14 \mathrm{gm} .(4+5+5)$

Maintenance dose -5 gm. 50\% mgso $_{4}$ IM every 4 hours

- Both regimes were continued for 24 hours after delivery or last convulsion whichever was later.

- If convulsion recurs within $30 \mathrm{~min}$ after loading dose, no additional MgSo4 was required

- If convulsion occurs 30 minutes after loading dose, additional 2gms MgSo4 was given IV

- Following observations were made with both regimes

1. Knee reflex ( should be present)

2. Urine output ( $>30 \mathrm{~m} 1$ hour)

3. Respiratory rate ( $>14 / \mathrm{mm}$ 's)

Serum $\mathrm{Mgso}_{4}$ levels were estimated for both regimes

First sample - 30 minutes after loading dose

Second sample -3 hours after loading dose

\section{RESULTS:}

1) Majority of the patients were primigravida (61\%), between age group 21 to 25 years (76\%), with weight less than $50 \mathrm{~kg}(74 \%)$

2) Success rate in controlling convulsions was $90 \%$ (low dose regime) There was no convulsion in Imminent eclampsia with either regime. 
3) The average $\mathrm{Mgso}_{4}$ required $54.5 \%$ less in low dose regime than that required for Pritchard regime. This reduced the cost of therapy.

4) The average serum $\mathrm{mg}^{++}$levels with low dose regime were $3.36 \mathrm{mg} \%$ and $4.05 \mathrm{mg} \%$ with Pritchard regime.

5) No significant maternal or neonatal complication in any group.

CONCLUSION: Low dose $\mathrm{mgSO}_{4}$ regime is as effective as Pritchard regime, with less requirement of the drug.

DISCUSSION: Pre eclampsia \& eclampsia are common pregnancy complications accounting for high maternal \& perinatal morbidity / mortality. Control \& prevention of convulsions is an important aspect of eclampsia management.

Dr. Pritchard from Parkland Hospital USA used $\mathrm{MgSo}_{4}$ anticonvulsant regime with high success rate. He commented that the dose of $\mathrm{MgSo}_{4}$ should be limited in women who are low weight otherwise the drug toxicity can occur

Dr. Flower etal 5. Adjusted doses according to body weight, plasma level.

In present study $74 \%$ Patients weigh less than $50 \mathrm{~kg}$ The very purpose of the study was to find if lower dose of $\mathrm{MgSo}_{4}$ is as efficacious as Pritchard regime.

In the study of Dr. Suman Sardesai \& Present study 20 gm. of $\mathrm{MgSo}_{4}$ was required in majority of cases

Rashid Begam et al 6. Required 28 gm. of $\mathrm{MgSo}_{4}$ while Pritchard regime needed $44 \mathrm{gm}$. of $\mathrm{MgSo}_{4}$.

The success rate in controlling convulsions was $90 \%$ in present study with low dose which is comparable with Dr. Sardesai's study (91\%)

While that with Pritchard regime was $91.6 \%$

There is controversy regarding effective therapeutic level of serum mg

It was $3.36 \mathrm{mg} \%$ with low dose \& $4.05 \mathrm{mg} \%$ with Pritchard regime

These findings are consistent with that of Dr. Sardesai study (3.14 to 6 ) Zuspan (3 to 4 ) \& Cruikshank (3.3to 4.4 )

ACKNOWLEDGMENT: We thank Medical Director, KIMS, Karad for allowing us to use \& Publish the data related to Patients

\section{REFERENCES:}

1. Bhargava et al J Obstet Gynecol India $2006 ; 5: 402$

2. Raksha et al Determinants of maternal mortalityin eclampsia in India. AustraliaNZ J Obstet Gynecol 1994:34;537

3. Govt. of India ( sample Registration system ) internal mortality in India 1997-2003) Register General India, New Delhi.

4. Pritchard JA, Cunningham FG: The Parkland memorial hospital Protocol for treatment of eclampsia: Evaluation of 245 cases AmJobstetGynecol 1984;148: 951.

5. Magpie trial collaborative group : A randomised placebo controlled trial. Lancet.2002; $359: 1877$.

6. Sardesai suman, Patil Ajit etal : Low dose mgso ${ }_{4}$ therapy for eclampsia and imminent eclampsia, regime tailored for India women. J obstetGynecol India.2003; 53;546 
7. Flower C A: Magnesium sulphate in toxaemia of pregnancy new dosage schedule based on body weight. J obstetGynecol India. 1962; $19: 315$

8. Rashida Begam, Anwara Begam : A low ( Dhaka) mgso 4 regime for eclampsia. Actaobstetrica \& Gynecologica 2001; 80: 998

1.Table - I Weight distribution

\begin{tabular}{|l|l|l|l|}
\hline Wt.in kg. & Low dose & Pritchard & Total \\
\hline$<40$ & 9 & 2 & $11(9.17 \%)$ \\
\hline 40 to45 & 18 & 21 & $39(32.50 \%)$ \\
\hline 46 to50 & 18 & 21 & $39(32.50 \%)$ \\
\hline 51 to55 & 6 & 10 & $16(13.33 \%)$ \\
\hline 56 to60 & 4 & 3 & $7(5.83 \%)$ \\
\hline$>60$ & 5 & 3 & $8(6.67 \%)$ \\
\hline
\end{tabular}

2.Table -II Total dose of mgso4 reguired (in grams)

\begin{tabular}{|l|l|l|}
\hline Mgso4 in grams & Low dose & Pritchard \\
\hline$<10$ & 5 & 0 \\
\hline 11 to 20 & 39 & 1 \\
\hline 21 to 30 & 15 & 0 \\
\hline 31 to 40 & 1 & 14 \\
\hline 41 to 50 & 0 & 28 \\
\hline 51 to 60 & 0 & 8 \\
\hline 61to70 & 0 & 5 \\
\hline 71 to 80 & 0 & 2 \\
\hline$>80$ & 0 & 2 \\
\hline
\end{tabular}

3. Table III Control of convulsions in both groups

\begin{tabular}{|l|l|l|l|l|}
\hline Number $\begin{array}{r}\text { of } \\
\text { convulsions } \\
\text { treatment }\end{array}$ & Low dose & Pritchard \\
\cline { 2 - 5 } & No.of pts & $\%$ & No.of pts & $\%$ \\
\hline None & 54 & 90 & 55 & 91.67 \\
\hline One & 5 & 8.33 & 4 & 6.67 \\
\hline More than one & 1 & 1.67 & 1 & 1.67 \\
\hline
\end{tabular}

By applying Chi square test it is statistically insignificant $(\mathrm{P}>0.05)$

4.Table - IV Average serum Magnesium levels

\begin{tabular}{|l|l|l|}
\hline \multirow{2}{*}{} & \multicolumn{2}{|c|}{ Serum mg } \\
\cline { 2 - 3 } & Sample I & Sample II \\
\hline Low dose & 3.36 & 3.36 \\
\hline Pritchard & 4.34 & 4.32 \\
\hline P value & $<0.001$ & $<0.001$ \\
\hline
\end{tabular}

Sample 1: 30 min after loading dose Sample 2: 3 hours after last dose

Applying $\mathrm{T}$ test it was found that there is significant difference $(\mathrm{P}<0.001)$ in serum mg levels 


\section{ORIGINAL ARTICLE}

Table V: Cost of therapy in rupees

\begin{tabular}{|l|l|l|}
\hline Cost in Rs. & Low dose regime & Pritchard regime \\
\hline$<100$ & 8 & 0 \\
\hline 100 to 300 & 52 & 5 \\
\hline 301 to 500 & 0 & 47 \\
\hline 501 to 700 & 0 & 8 \\
\hline
\end{tabular}

6.Table - VI Complications related to $\mathrm{MgSo}_{4}$

\begin{tabular}{|l|l|}
\hline Low dose & 0 \\
\hline Pritchard & 1 \\
\hline
\end{tabular}

One Patient in Pritchard group had respiratory depression 